\title{
Transcervical Radiofrequency Ablation of Uterine Fibroids Global Registry (SAGE): Study Protocol and Preliminary Results [Corrigendum]
}

Christoffel L, Römer T, Schiermeier S. Med Devices (Auckl). 2021;14:77-84.

Page 83, left column, lines $7-9$, it is stated that "These initial results corroborate those from previous clinical trials, as well as over 600 commercial cases worldwide". The text should read: "...as well as over 1,600 commercial cases worldwide".

The authors apologize for this error

\section{Publish your work in this journal}

Medical Devices: Evidence and Research is an international, peerreviewed, open access journal that focuses on the evidence, technology, research, and expert opinion supporting the use and application of medical devices in the diagnosis, monitoring, treatment and management of clinical conditions and physiological processes. The identification of novel devices and optimal use of existing devices which will lead to improved clinical outcomes and more effective patient management and safety is a key feature of the journal. The manuscript management system is completely online and includes a very quick and fair peer-review system. Visit http:// www.dovepress.com/testimonials.php to read real quotes from published authors. 